\title{
Distribution and conservation status of fairy shrimps (Crustacea: Anostraca) in the astatic soda pans of the Carpathian basin: the role of local and spatial factors
}

\author{
Zsófia HORVÁTH,,${ }^{1,2 *}$ Csaba Ferenc VAD, ${ }^{1}$ Lajos VÖRÖS, ${ }^{3}$ Emil BOROS ${ }^{4}$ \\ ${ }^{1}$ Department of Systematic Zoology and Ecology, Eötvös Loránd University, Pázmány Péter sétány 1/C, H-1117 Budapest, Hungary; \\ ${ }^{2}$ WasserCluster Lunz, Dr. Carl Kupelwieser Promenade 5, A-3293 Lunz am See, Austria; ${ }^{3}$ Balaton Limnological Institute, Centre for \\ Ecological Research, Hungarian Academy of Sciences, Klebelsberg Kuno u. 3, H-8237 Tihany, Hungary; ${ }^{4}$ Kiskunság National Park \\ Directorate, Liszt Ferenc u. 19, H-6000 Kecskemét, Hungary. \\ *Corresponding author: hhzsofia@gmail.com
}

\begin{abstract}
The distribution of Branchinecta orientalis, B. ferox and Chirocephalus carnuntanus was assessed in the natural and semi-natural astatic soda pans of the Carpathian basin. In Europe, these habitats are exclusively restricted to Hungary (Great Hungarian Plain), Austria (Seewinkel) and Serbia (Vojvodina). The present research is the first comprehensive large-scale study - covering an area of approximately 125,000 $\mathrm{km}^{2}$ - on these three fairy shrimp species in the region, and it is important especially in the case of Branchinecta spp., due to former taxonomical uncertainties. The local, land use and spatial effects on the species distribution were also analysed. The three anostracans were found to adopt different strategies, mainly according to the salinity of the pans. The apparently halophilous B. orientalis tolerated higher salinities than the other species, which can be regarded as habitat-generalist halotolerants, showing a high preference for soda waters in Central Europe. The density of the species was significantly affected only by local factors, while their occurrence was influenced also by pan isolation. Land use did not explain a significant amount of variation in either case. In conclusion, soda pans with a wide range of different salinities constitute a suitable habitat for all the three species. Also, protected areas with high number of pans - as Seewinkel (in Austria) or Kiskunság (in Hungary) - can play an essential role in the long-term conservation of these anostracans. Finally, we suggest that these species should be legally protected, primarily because the number of their habitats in the basin is seriously declining.
\end{abstract}

Key words: Pannonian plain, salinity, Branchinecta, Chirocephalus, isolation.

Received: April 2012. Accepted: September 2012.

\section{INTRODUCTION}

Large branchiopods (Anostraca, Notostraca, Spinicaudata and Laevicaudata) are important flagship species of temporary waters (Belk, 1998). Human disturbance and destruction of their often neglected natural habitats caused them to be globally vulnerable and to undergo a serious decline of their distribution (Löffler, 1993; Petrov and Petrov, 1997; Belk, 1998; Damgaard and Olesen, 1998; Samraoui et al., 2006; Brendonck et al., 2008; Demeter and Stoicescu, 2008). Moreover, as our knowledge about this group is still scarce, not only is it important to monitor them, but also to study their ecological needs and roles (Forró, 2000; Mura, 2001; Demeter and Stoicescu, 2008). In Austria, they have been recently studied in depth (e.g., Metz and Forró, 1991; Eder et al., 1996, 1997; Gottwald and Eder, 1999; Eder and Hödl, 2002, 2003), but their investigation in Serbia began only in the 1970s (Petrov and Petrov, 1997). Likewise, they have not been surveyed since the 1990s, except for some faunistical notes from the south-eastern part of the country (Miličić and Petrov, 2007). In Hungary, only one investigation has targeted large branchiopods since the 1960s (Boven et al., 2008), and a very few studies included them with new occurrences (e.g., Forró, 1990, 2003; Boros et al., 2006; Horváth and Vad, 2010).

In the astatic soda pans of the Carpathian basin, three Anostraca species were recorded: Branchinecta ferox (Milne-Edwards, 1840), B. orientalis Sars, 1901 and Chirocephalus carnuntanus (Brauer, 1877) (Petkovski, 1991; Löffler, 1993; Eder et al., 1997; Petrov and Petrov, 1997). Although other large branchiopods are testified to occur, e.g. in the Seewinkel and Kiskunság areas, these flagship species were mainly registered in temporary puddles, flooded meadows, or sometimes in former pans that had already lost the characteristics of astatic soda pans (Eder et al., 1996; Boven et al., 2008). There are no occurrences of any other species from natural, saline soda pans. The three anostracans under discussion are mainly univoltine (Löffler, 1993; Eder, et al., 1997) as they generally occur in early spring and disappear as water temperature increases. Eder et al. (1997) found them in Austria exclusively in spring, but Petkovski (1991) noted that $B$. orientalis can sometimes be present also in late autumn.

The Branchinecta species have a disjunct distribution 
(Alonso, 1985; Brtek and Thiéry, 1995). B. orientalis is a Mongolian-steppic element (Brtek and Thiéry, 1995), but it is also present in the Asian high mountains (Brtek and Thiéry, 1995; Manca and Mura, 1997). B. ferox occurs in the temporary waters of steppes and steppe-like habitats across the Mediterranean Europe and in North Africa (Dimentman, 1981; Fryer, 1983; Alonso, 1985), but it also lives in some parts of Asia (Brtek and Thiéry, 1995). C. carnuntanus also inhabits astatic habitats (Eder et al., 1997), but with a much more restricted distribution. Apart from two exceptions [Moscow and the no-longer-existing northern Bohemian lowland (Brtek and Thiéry, 1995; Lukáš Merta, personal communication)], it is only present in the Carpathian basin (Brtek and Thiéry, 1995), and Löffler (1993) regarded it as an endemic Pannonian species. Before Petkovski's (1991) taxonomical revision, some former studies from the region did not differentiate between B. orientalis and B. ferox; therefore, Eder and Hödl (2003) suggested using Austrian data published before 1991 as Branchinecta spp.

Given the biogeographical importance of the Carpathian basin in the distribution of the three species (meaning presumably the exceptional area of occurrence for $C$. carnuntanus and the main European patch for the Branchinecta species) and the former uncertainties regarding the taxonomy of the two Branchinecta species before Petkovski (1991), a comprehensive survey of this region is needed.

In our study, we aimed to: i) update knowledge on the distribution of the three anostracan species in the European astatic soda pans (which unique habitat type is now restricted exclusively to Hungary, Austria and Serbia); ii) assess their current conservation status; and iii) determine the local, land use and spatial effects on their distribution.

\section{METHODS}

\section{Study area}

Shallow astatic soda pans are typical examples of steppic aquatic habitats in the lowland territory of the Carpathian basin; also, they are a special type of inland athalassohaline waters (Hammer, 1986). They have notable seasonal water level fluctuations and frequently dry out entirely in midsummer or autumn. Their high $\mathrm{pH}$ and salinity is caused by a high amount of dissolved sodium-hydrogencarbonate, and their salinity varies between hypo- and meso-saline ranges, depending on the water level (Metz and Forró, 1991; Boros, 1999; Dvihally, 1999). Most of them are highly turbid because of permanently suspended colloidal ion complexes and/or high concentration of dissolved humic substances (Boros, 1999; V.-Balogh et al., 2010). Along the shoreline, characteristic sodic-alkaline soils can be found with the typical sodic marshland and wet meadow vegetation (e.g., Bolboschoenus-Phragmitetum and Lep-
idio-Puccinellietum associations). Conversely, no vegetation is present in the major part of the lakebed during the wet periods (Boros, 1999).

The Carpathian basin is the westernmost occurrence of soda pans in Eurasia (parallel with the steppe biome), while it is their only occurrence in Europe (Hammer, 1986). In the last few decades soda pans have been dramatically decreased in number, and this unique habitat type is now restricted only to the lowland parts of Hungary, to Seewinkel in Austria and to Vojvodina in Serbia (Boros, 1999).

\section{Data on sampling and species}

Ninety-one astatic soda pans in the Carpathian basin were considered in the study (see Tab. 1 for their coding), in an area of approximately $125,000 \mathrm{~km}^{2}$ (Fig. 1). We included every pan, apart from reconstruction areas and those that had already lost all their sodic characteristics, mostly by severe anthropogenetic alteration. Among the pans, 51 were located in Hungary, 31 in Austria (Seewinkel) and 9 in Serbia (Vojvodina). All of them were sampled at least twice: i) between $4^{\text {th }}$ March and $9^{\text {th }}$ April 2010 for the early spring sampling; and ii) between $11^{\text {th }}$ May and $20^{\text {th }}$ June 2009 or between $12^{\text {th }}$ May and $2^{\text {nd }}$ June 2010 for the early summer sampling. Sampling was conducted in the open water of all pans. As the species have a relatively short life-span, only early spring samples were included in the evaluation of the effects of environmental variables, while summer samples were used only as additional faunistic data.

Twenty litres of water for a zooplankton sample were randomly collected with a one-litre plastic beaker and sieved through a plankton net with a mesh size of $30 \mu \mathrm{m}$ in each pan for fairy shrimp nauplii and metanauplii.

A push net - similar to the sledge dredge that Jungwirth (1973) used to collect Branchinecta in a soda pan with a mesh size of $1 \mathrm{~mm}$ and an opening of $17 \mathrm{~cm}$ was used to collect anostracans. In each pan, a transect was pushed in the open water. It was $30 \mathrm{~m}$ in length, but it was reduced to $10 \mathrm{~m}$ in summer due to the very high abundances of Heteroptera. Samples were preserved in a $70 \%$ ethanol solution. Identification was based on Eder and Hödl (1996), and the numbers and densities of anostracans were also determined.

\section{Environmental variables}

Water depth and Secchi disk transparency were measured at each sampling location. Conductivity, $\mathrm{pH}$, and dissolved $\mathrm{O}_{2}$ concentration were determined by using a WTW Multiline P4 field equipment with TetraCon 325 and SenTix 41 electrodes (WTW Wissenschaftlich-Technische Werkstätten GmbH, Weilheim, Germany). Total suspended solids (TSS) concentration was measured by filtering water 
Tab. 1. List of the soda pans with their location, coding and the occurrence of species.

\begin{tabular}{|c|c|c|c|c|c|c|c|c|}
\hline Code* & Settlement & Pan & Latitude (N) & Longitude (E) & B. $f$. & B. $o$. & C. c. & Only nauplii \\
\hline H01 & Aba & Fényes-tó & $47^{\circ} 3 ’ 37.309^{\prime \prime}$ & $18^{\circ} 27^{\prime} 52.682^{\prime \prime}$ & & & & + \\
\hline H02 & Aba & Sóstó & $47^{\circ} 3^{\prime} 13.926^{\prime \prime}$ & $18^{\circ} 28^{\prime} 20.608^{\prime \prime}$ & & & & + \\
\hline H03 & Apaj & Alsó-szúnyog & $47^{\circ} 8^{\prime} 28.019^{\prime \prime}$ & $19^{\circ} 6{ }^{\prime} 54.202^{\prime \prime}$ & & & & \\
\hline H04 & Bácsalmás & Sóstó & $46^{\circ} 5^{\prime} 48.565^{\prime \prime}$ & $19^{\circ} 19^{\prime} 53.338^{\prime \prime}$ & & + & & \\
\hline H05 & Balástya & Müller-szék & $46^{\circ} 27^{\prime} 4.581^{\prime \prime}$ & $19^{\circ} 59^{\prime} 21.788^{\prime \prime}$ & & & & \\
\hline H06 & Balástya & Ősze-szék & $46^{\circ} 24^{\prime} 6.123^{\prime \prime}$ & $19^{\circ} 59^{\prime} 4.185^{\prime \prime}$ & & & & \\
\hline H07 & Csongrád & Kis-sóstó & $46^{\circ} 44^{\prime} 27.456^{\prime \prime}$ & $19^{\circ} 59^{\prime} 31.848^{\prime \prime}$ & + & & & \\
\hline H08 & Derecske & Bocskoros-szik & $47^{\circ} 20^{\prime} 11.583^{\prime \prime}$ & $21^{\circ} 30^{\prime} 49.906^{\prime \prime}$ & & & & \\
\hline H09 & Derecske & Peres-szik & $47^{\circ} 22^{\prime} 39.048^{\prime \prime}$ & $21^{\circ} 34^{\prime} 30.972^{\prime \prime}$ & & & & \\
\hline H10 & Dunatetétlen & Bába-szék & $46^{\circ} 44^{\prime} 22.275^{\prime \prime}$ & $19^{\circ} 9^{\prime} 1.597^{\prime \prime}$ & & & & \\
\hline H11 & Dunatetétlen & Böddi-szék (N Pool) & $46^{\circ} 45^{\prime} 57.078^{\prime \prime}$ & $19^{\circ} 9^{\prime} 24.774 "$ & & & + & \\
\hline H12 & Dunatetétlen & Böddi-szék (SE Pool) & $46^{\circ} 45^{\prime} 24.71^{\prime \prime}$ & $19^{\circ} 9^{\prime} 23.95^{\prime \prime}$ & & + & + & \\
\hline H13 & Dunatetétlen & Böddi-szék (SW Pool) & $46^{\circ} 45^{\prime} 24.12^{\prime \prime}$ & $19^{\circ} 9^{\prime} 15.56^{\prime \prime}$ & & + & + & \\
\hline H14 & Dunatetétlen & Böddi-szék (W Pool) & $46^{\circ} 45^{\prime} 53.15^{\prime \prime}$ & $19^{\circ} 8^{\prime} 51.91^{\prime \prime}$ & & + & + & \\
\hline H15 & Dunatetétlen & Füzfa-szék & $46^{\circ} 47^{\prime} 29.112^{\prime \prime}$ & $19^{\circ} 9^{\prime} 29.274^{\prime \prime}$ & & & + & \\
\hline H16 & Dunatetétlen & Sósér & $46^{\circ} 47^{\prime} 18.530^{\prime \prime}$ & $19^{\circ} 8 ’ 39.382^{\prime \prime}$ & & & & \\
\hline H17 & Fülöpszállás & Fehér-szék & $46^{\circ} 48^{\prime} 28.496^{\prime \prime}$ & $19^{\circ} 11^{\prime} 15.912^{\prime \prime}$ & & & & \\
\hline H18 & Fülöpszállás & Kelemen-szék & $46^{\circ} 47^{\prime} 50.480^{\prime \prime}$ & $19^{\circ} 10^{\prime} 59.149^{\prime \prime}$ & + & + & + & \\
\hline H19 & Gárdony & Dinnyési-fertő & $47^{\circ} 10^{\prime} 12.328^{\prime \prime}$ & $18^{\circ} 32^{\prime} 45.152^{\prime \prime}$ & & & & \\
\hline $\mathrm{H} 20$ & Hajdúböszörmény & Móricz-szik & $47^{\circ} 42^{\prime} 46.801^{\prime \prime}$ & $21^{\circ} 21^{\prime} 50.606^{\prime \prime}$ & & & & \\
\hline $\mathrm{H} 21$ & Hosszúpályi & Fehér-tó & $47^{\circ} 19^{\prime} 1.250^{\prime \prime}$ & $21^{\circ} 44^{\prime} 10.158^{\prime \prime}$ & & & & \\
\hline $\mathrm{H} 22$ & Hosszúpályi & Petrovics-lapos & $47^{\circ} 20^{\prime} 12.572^{\prime \prime}$ & $21^{\circ} 43^{\prime} 47.257^{\prime \prime}$ & & & & \\
\hline $\mathrm{H} 23$ & Jászkarajenő & Csukáséri-tó no. I & $47^{\circ} 1^{\prime} 3.760^{\prime \prime}$ & $20^{\circ} 3^{\prime} 32.226^{\prime \prime}$ & & + & & \\
\hline $\mathrm{H} 24$ & Jászkarajenő & Csukáséri-tó no. II & $47^{\circ} 1^{\prime} 5.511^{\prime \prime}$ & $20^{\circ} 3^{\prime} 40.806^{\prime \prime}$ & & & & + \\
\hline $\mathrm{H} 25$ & Jászszentlászló & Kerek-tó & $46^{\circ} 34^{\prime} 4.091 "$ & $19^{\circ} 45^{\prime} 0.619^{\prime \prime}$ & & & & \\
\hline H26 & Kardoskút & Fehér-tó & $46^{\circ} 28^{\prime} 6.045^{\prime \prime}$ & $20^{\circ} 37^{\prime} 1.796 "$ & & & & \\
\hline $\mathrm{H} 27$ & Kaskantyú & Sárkány-tó & $46^{\circ} 40^{\prime} 27.500^{\prime \prime}$ & $19^{\circ} 20^{\prime} 43.023^{\prime \prime}$ & & & & \\
\hline $\mathrm{H} 28$ & Királyhegyes & Csikóspusztai-tó & $46^{\circ} 17^{\prime} 31.291^{\prime \prime}$ & $20^{\circ} 38^{\prime} 6.123^{\prime \prime}$ & & & & \\
\hline H29 & Kistelek & Tóalj & $46^{\circ} 28^{\prime} 39.234^{\prime \prime}$ & $19^{\circ} 58^{\prime} 2.616^{\prime \prime}$ & & & & + \\
\hline $\mathrm{H} 30$ & Konyár & Kerek-szik & $47^{\circ} 20^{\prime} 23.818^{\prime \prime}$ & $21^{\circ} 39^{\prime} 10.249^{\prime \prime}$ & + & & & \\
\hline H31 & Mezöberény & Medvefejes-tó & $46^{\circ} 50^{\prime} 14.596^{\prime \prime}$ & $21^{\circ} 2^{\prime} 3.792^{\prime \prime}$ & & & & \\
\hline H32 & Nyíregyháza & Nagy-Széksóstó & $47^{\circ} 55^{\prime} 8.412^{\prime \prime}$ & $21^{\circ} 37^{\prime} 58.084^{\prime \prime}$ & & & & \\
\hline H33 & Ópusztaszer & Sárgatanyai-tó & $46^{\circ} 27^{\prime} 35.546^{\prime \prime}$ & $20^{\circ} 2^{\prime} 52.938^{\prime \prime}$ & & & & \\
\hline H34 & Orosháza & Kis-sóstó & $46^{\circ} 31^{\prime} 25.466^{\prime \prime}$ & $20^{\circ} 37^{\prime} 48.043^{\prime \prime}$ & & & & \\
\hline H35 & Pálmonostora & Pallagi-szék & $46^{\circ} 35^{\prime} 15.471^{\prime \prime}$ & $19^{\circ} 54^{\prime} 55.547^{\prime \prime}$ & & & & + \\
\hline H36 & Pálmonostora & Kis-Péteri-tó & $46^{\circ} 35^{\prime} 12.738^{\prime \prime}$ & $19^{\circ} 54^{\prime} 31.950^{\prime \prime}$ & & & & + \\
\hline H37 & Pusztaszer & Büdös-szék & $46^{\circ} 32^{\prime} 46.511^{\prime \prime}$ & $20^{\circ} 1^{\prime} 58.153^{\prime \prime}$ & + & & + & \\
\hline $\mathrm{H} 38$ & Pusztaszer & Vesszős-szék & $46^{\circ} 31^{\prime} 27.615^{\prime \prime}$ & $20^{\circ} 2 ’ 20.122^{\prime \prime}$ & & & & \\
\hline H39 & Sárkeresztúr & Sárkány-tó & $46^{\circ} 59^{\prime} 8.620^{\prime \prime}$ & $18^{\circ} 32^{\prime} 54.133^{\prime \prime}$ & & & & + \\
\hline $\mathrm{H} 40$ & Sárszentágota & Sóstó & $46^{\circ} 58^{\prime} 18.426^{\prime \prime}$ & $18^{\circ} 33^{\prime} 12.224^{\prime \prime}$ & & & & \\
\hline H41 & Solt & Bogárzó & $46^{\circ} 48^{\prime} 28.906^{\prime \prime}$ & $19^{\circ} 8^{\prime} 28.562^{\prime \prime}$ & + & + & + & \\
\hline $\mathrm{H} 42$ & Soltszentimre & unnamed & $46^{\circ} 45^{\prime} 48.462^{\prime \prime}$ & $19^{\circ} 10^{\prime} 50.531^{\prime \prime}$ & & + & & \\
\hline $\mathrm{H} 43$ & Soponya & Sóstó & $47^{\circ} 0{ }^{\prime} 18.226^{\prime \prime}$ & $18^{\circ} 29^{\prime} 28.011^{\prime \prime}$ & & & & \\
\hline H44 & Szabadszállás & Büdös-szék & $46^{\circ} 51^{\prime} 57.757^{\prime \prime}$ & $19^{\circ} 10^{\prime} 9.430^{\prime \prime}$ & + & + & + & \\
\hline H45 & Szabadszállás & Pipás-szék & $46^{\circ} 52^{\prime} 33.824^{\prime \prime}$ & $19^{\circ} 10^{\prime} 35.302^{\prime \prime}$ & & & + & \\
\hline H46 & Szabadszállás & Zab-szék & $46^{\circ} 50^{\prime} 15.061^{\prime \prime}$ & $19^{\circ} 10^{\prime} 11.207^{\prime \prime}$ & + & + & + & \\
\hline H47 & Tiszafüred & Meggyes-lapos & $47^{\circ} 33^{\prime} 25.222^{\prime \prime}$ & $20^{\circ} 53^{\prime} 51.439^{\prime \prime}$ & & & & \\
\hline $\mathrm{H} 48$ & Tiszavasvári & Fehér-szik & $47^{\circ} 57^{\prime} 43.928^{\prime \prime}$ & $21^{\circ} 25^{\prime} 8.480^{\prime \prime}$ & & & & + \\
\hline H49 & Tiszavasvári & Göbölyös & $47^{\circ} 56^{\prime} 26.217^{\prime \prime}$ & $21^{\circ} 25^{\prime} 36.453^{\prime \prime}$ & & & & \\
\hline H50 & Tömörkény & Dong-ér & $46^{\circ} 34^{\prime} 7.544^{\prime \prime}$ & $20^{\circ} 3^{\prime} 46.483^{\prime \prime}$ & & & & \\
\hline \multirow[t]{2}{*}{ H51 } & Újfehértó & Nagy-Vadas-tó & $47^{\circ} 51^{\prime} 31.388^{\prime \prime}$ & $21^{\circ} 39^{\prime} 24.065^{\prime \prime}$ & & + & & \\
\hline & & & & Occurrence in Hungary & 7 & 11 & 11 & 8 \\
\hline A01 & Apetlon & Apetloner Meierhoflacke & $47^{\circ} 43^{\prime} 17.673^{\prime \prime}$ & $16^{\circ} 49^{\prime} 26.545^{\prime \prime}$ & & & & \\
\hline A02 & Apetlon & Birnbaumlacke & $47^{\circ} 49^{\prime} 3.775^{\prime \prime}$ & $16^{\circ} 51^{\prime} 53.678^{\prime \prime}$ & + & & & \\
\hline A03 & Apetlon & Darscho (Warmsee) & $47^{\circ} 46^{\prime} 13.079^{\prime \prime}$ & $16^{\circ} 50^{\prime} 24.694^{\prime \prime}$ & & & & \\
\hline A04 & Apetlon & Große Neubruchlacke & $47^{\circ} 47^{\prime} 10.036^{\prime \prime}$ & $16^{\circ} 50^{\prime} 31.914^{\prime \prime}$ & & + & & \\
\hline A05 & Apetlon & Kühbrunnlacke & $47^{\circ} 47^{\prime} 33.848^{\prime \prime}$ & $16^{\circ} 52^{\prime} 43.053^{\prime \prime}$ & + & + & & \\
\hline A06 & Apetlon & Lange Lacke & $47^{\circ} 45^{\prime} 26.911^{\prime \prime}$ & $16^{\circ} 52^{\prime} 43.553^{\prime \prime}$ & & + & & \\
\hline A07 & Apetlon & Martenhofen-lacken & $47^{\circ} 45^{\prime} 1.806^{\prime \prime}$ & $16^{\circ} 51^{\prime} 24.102^{\prime \prime}$ & & + & & \\
\hline A08 & Apetlon & Neufeldlacke & $47^{\circ} 45^{\prime} 52.116^{\prime \prime}$ & $16^{\circ} 50^{\prime} 24.894^{\prime \prime}$ & & & & \\
\hline A09 & Apetlon & Ochsenbrunnlacke & $47^{\circ} 48^{\prime} 38.649^{\prime \prime}$ & $16^{\circ} 50^{\prime} 40.622^{\prime \prime}$ & & & + & \\
\hline A10 & Apetlon & Östliche Wörthenlacke & $47^{\circ} 46^{\prime} 24.037^{\prime \prime}$ & $16^{\circ} 52^{\prime} 48.338^{\prime \prime}$ & & & & \\
\hline A11 & Apetlon & Östliche-Fuchslochlacken & $47^{\circ} 47^{\prime} 25.587^{\prime \prime}$ & $16^{\circ} 51^{\prime} 58.269^{\prime \prime}$ & & $\stackrel{+}{\text { To be }}$ & ntinue & on next page \\
\hline
\end{tabular}


Tab. 1. Continued from previous page.

\begin{tabular}{|c|c|c|c|c|c|c|c|c|}
\hline Code* & Settlement & Pan & Latitude $(\mathrm{N})$ & Longitude (E) & B. $f$. & B. $o$. & C. c. & Only naupli \\
\hline A12 & Apetlon & Sechsmahdlacke & $47^{\circ} 47^{\prime} 1.639^{\prime \prime}$ & $16^{\circ} 53^{\prime} 2.803^{\prime \prime}$ & & + & & \\
\hline A13 & Apetlon & Stundlacke & $47^{\circ} 47^{\prime} 56.054^{\prime \prime}$ & $16^{\circ} 52^{\prime} 18.143^{\prime \prime}$ & & & & \\
\hline A14 & Apetlon & Unterer Weißsee & $47^{\circ} 43^{\prime} 36.432^{\prime \prime}$ & $16^{\circ} 49^{\prime} 34.386^{\prime \prime}$ & & & & \\
\hline A15 & Apetlon & Westliche Wörthenlacke & $47^{\circ} 46^{\prime} 15.318^{\prime \prime}$ & $16^{\circ} 52^{\prime} 14.796^{\prime \prime}$ & & & & \\
\hline A16 & Apetlon & Westliche-Fuchslochlacken & $47^{\circ} 47^{\prime} 24.276^{\prime \prime}$ & $16^{\circ} 51^{\prime} 8.458^{\prime \prime}$ & & + & & \\
\hline A17 & Illmitz & Albersee & $47^{\circ} 46^{\prime} 30.491^{\prime \prime}$ & $16^{\circ} 46^{\prime} 12.429^{\prime \prime}$ & & + & & \\
\hline $\mathrm{A} 18$ & Illmitz & Auerlacke & $47^{\circ} 47^{\prime} 21.015^{\prime \prime}$ & $16^{\circ} 53^{\prime} 12.400^{\prime \prime}$ & & & & \\
\hline A19 & Illmitz & Herrnsee & $47^{\circ} 44^{\prime} 40.432^{\prime \prime}$ & $16^{\circ} 46^{\prime} 11.955^{\prime \prime}$ & & & & \\
\hline $\mathrm{A} 20$ & Illmitz & Kirchsee & $47^{\circ} 45^{\prime} 31.243^{\prime \prime}$ & $16^{\circ} 47^{\prime} 7.759^{\prime \prime}$ & & + & & \\
\hline $\mathrm{A} 21$ & Illmitz & Krautingsee & $47^{\circ} 45^{\prime} 21.703^{\prime \prime}$ & $16^{\circ} 46^{\prime} 49.727^{\prime \prime}$ & & & & \\
\hline $\mathrm{A} 22$ & Illmitz & Mittlerer Stinkersee & $47^{\circ} 48^{\prime} 24.332^{\prime \prime}$ & $16^{\circ} 47^{\prime} 15.079^{\prime \prime}$ & & + & & \\
\hline $\mathrm{A} 23$ & Illmitz & Obere Höllacke & $47^{\circ} 49^{\prime} 37.630^{\prime \prime}$ & $16^{\circ} 48^{\prime} 28.556^{\prime \prime}$ & & + & & \\
\hline A24 & Illmitz & Oberer Stinkersee & $47^{\circ} 48^{\prime} 49.544^{\prime \prime}$ & $16^{\circ} 47^{\prime} 33.062^{\prime \prime}$ & & + & & \\
\hline A25 & Illmitz & Runde Lacke & $47^{\circ} 47^{\prime} 8.681^{\prime \prime}$ & $16^{\circ} 47^{\prime} 33.877^{\prime \prime}$ & & + & & \\
\hline A26 & Illmitz & Südlicher Silbersee & $47^{\circ} 47^{\prime} 28.078^{\prime \prime}$ & $16^{\circ} 46^{\prime} 47.053^{\prime \prime}$ & & & & \\
\hline A27 & Illmitz & Untere Höllacke & $47^{\circ} 49^{\prime} 19.618^{\prime \prime}$ & $16^{\circ} 48^{\prime} 23.611^{\prime \prime}$ & & & & \\
\hline A28 & Illmitz & Unterer Schrändlsee & $47^{\circ} 44^{\prime} 57.014^{\prime \prime}$ & $16^{\circ} 47^{\prime} 46.915^{\prime \prime}$ & & & & \\
\hline A29 & Illmitz & Unterer Stinkersee & $47^{\circ} 47^{\prime} 59.933^{\prime \prime}$ & $16^{\circ} 47^{\prime} 10.841^{\prime \prime}$ & & & & \\
\hline $\mathrm{A} 30$ & Illmitz & Zicksee & $47^{\circ} 46^{\prime} 1.072^{\prime \prime}$ & $16^{\circ} 47^{\prime} 5.107^{\prime \prime}$ & & & & \\
\hline \multirow[t]{2}{*}{ A31 } & St. Andrä & Baderlacke & $47^{\circ} 46^{\prime} 42.778^{\prime \prime}$ & $16^{\circ} 56^{\prime} 3.401^{\prime \prime}$ & & + & & \\
\hline & & & & Occurrence in Austria & 2 & 14 & 1 & - \\
\hline S01 & Baranda & Slatina & $45^{\circ} 4^{\prime} 58.001^{\prime \prime}$ & $20^{\circ} 29^{\prime} 29.481^{\prime \prime}$ & & & & \\
\hline S02 & Elemir & Okanj & $45^{\circ} 28^{\prime} 1.793^{\prime \prime}$ & $20^{\circ} 18^{\prime} 0.262^{\prime \prime}$ & & + & & \\
\hline $\mathrm{S} 03$ & Melenci & Mala Rusanda & $45^{\circ} 30^{\prime} 44.80^{\prime \prime}$ & $20^{\circ} 18^{\prime} 9.50^{\prime \prime}$ & & + & & \\
\hline S04 & Melenci & Veliko Rusanda & $45^{\circ} 31^{\prime} 17.336^{\prime \prime}$ & $20^{\circ} 18^{\prime} 25.502^{\prime \prime}$ & & & & \\
\hline S05 & Novi & Bečej Slano Kopovo & $45^{\circ} 37^{\prime} 30.806^{\prime \prime}$ & $20^{\circ} 12^{\prime} 36.085^{\prime \prime}$ & & + & & \\
\hline S06 & Čoka & Čoka Kopovo & $45^{\circ} 57^{\prime} 12.415^{\prime \prime}$ & $20^{\circ} 11^{\prime} 54.482^{\prime \prime}$ & & & & \\
\hline S07 & Kanjiža & Čudotvorni Bunar & $46^{\circ} 3 ’ 38.662^{\prime \prime}$ & $20^{\circ} 00^{\prime} 3.726^{\prime \prime}$ & & & & \\
\hline S08 & Stanišić & Bela Bara & $45^{\circ} 56^{\prime} 49.453^{\prime \prime}$ & $19^{\circ} 5^{\prime} 24.884^{\prime \prime}$ & + & & & \\
\hline \multirow[t]{3}{*}{ S09 } & Riđica & Medura & $45^{\circ} 59^{\prime} 31.516^{\prime \prime}$ & $19^{\circ} 7^{\prime} 59.560^{\prime \prime}$ & & + & & \\
\hline & & & & Occurrence in Serbia & 1 & 4 & - & - \\
\hline & & & & Total occurrence & 10 & 29 & 12 & 8 \\
\hline
\end{tabular}

*The first character of the code number stands for the country: H, Hungary; A, Austria; S, Serbia.

$N$, north; E, east; SE, south-east; SW, south-west; W, west; B. f., Branchinecta ferox; B. o., Branchinecta orientalis; C. c., Chirocephalus carnuntanus.

$(100-1000 \mathrm{~mL})$ through pre-dried and pre-weighted cellulose acetate filters after oven-drying at $105^{\circ} \mathrm{C}$.

Additional habitat characteristics were also determined. The pan area and the ratio of open water were calculated on the basis of georeferenced GoogleEarth satellite images with ArcGIS (ESRI, 2002). Two hydroperiod types with five levels were established: one for the permanence of open water in the lake bed (hydroperiod type 1) and one for the frequency of drying out (hydroperiod type 2).

For land use effects, we used water supply (artificial inflow), drainage melioration channelling (artificial outflow), disturbancy of the structure, grazing pressure (density of mainly Hungarian grey cattle or water buffalos on the pan and in the catchment area), grazing time (from no grazing through a few spring months to year-round), and catchment characteristics. Water supply, channelling, disturbancy of the lake bed, grazing pressure and time were determined with the help of information collected from managers of the pans (mainly workers of the national park directorates). The ratios of natural habitats (meadows, swamps, forests, etc.), agricultural fields and human settlements in the catchment area of each pan were calculated on the basis of georeferenced GoogleEarth satellite images with ArcGIS (ESRI, 2002).

For spatial effects, we calculated the nearest distance to the next pan, pan density (number of pans within an area with a radius of $20 \mathrm{~km}$ around each pan), and isolation (average distance of a pan from all the other sites).

\section{Statistical analysis}

All environmental variables (Tab. 2) were used in a forward selection procedure of redundancy analysis (RDA) to explore those variables which significantly explain the distribution of the three anostracan species. First, we identified the most important factors in determining the occurrence (presence-absence data) of each species. Forward selection revealed significant effects both among the habitat characteristics (conductivity, pan area and Secchi disk transparency) and spatial variables (isolation), which were used 


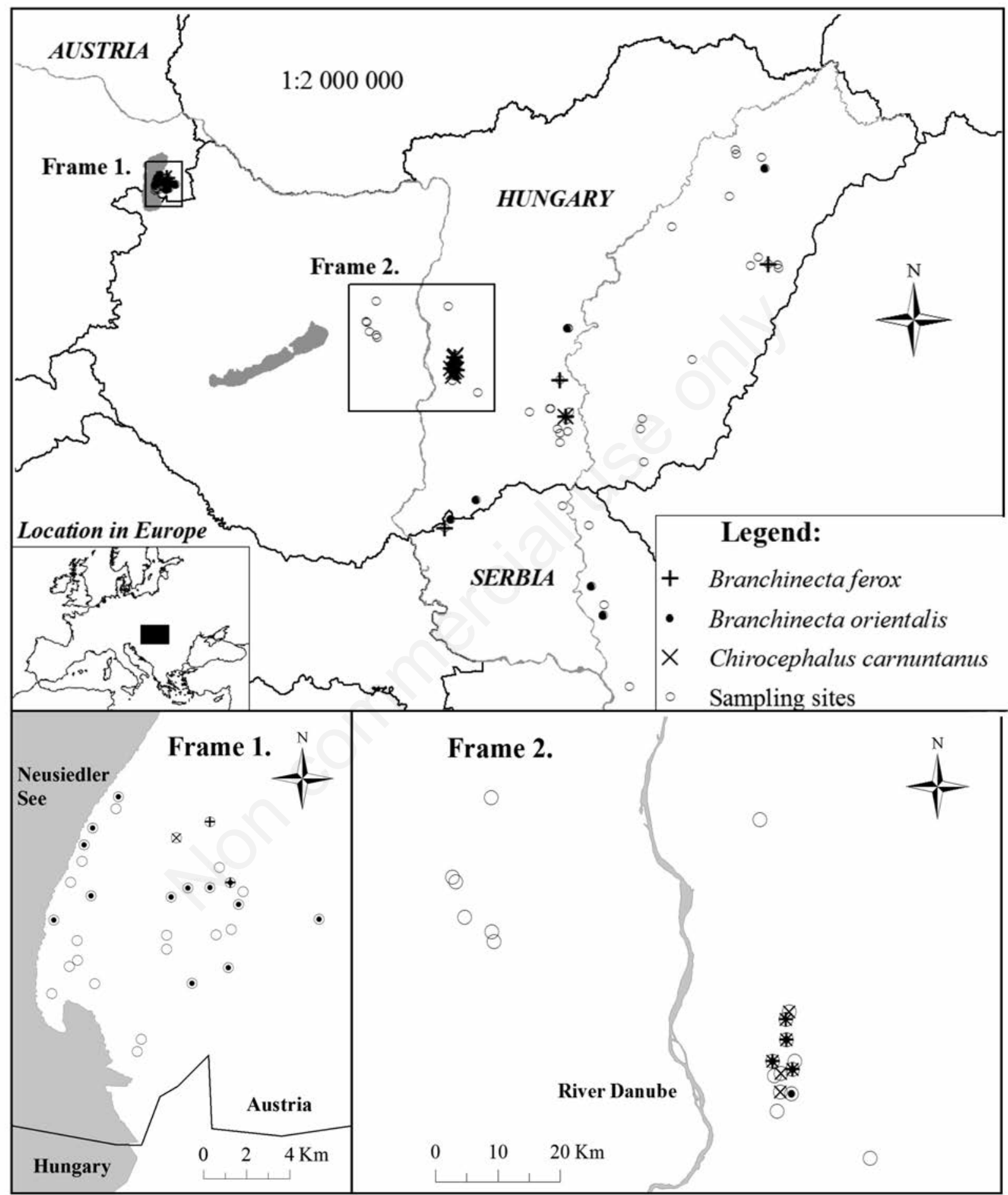

Fig. 1. Location of the soda pans in the Carpathian basin (open circles) and the distribution of the three Anostraca species. The enlarged frames show the clutches of soda pans: in Seewinkel in Austria (Frame 1); and in the middle section of the Danube valley in Hungary, with the pans of Kiskunság east of the Danube (Frame 2). 
in variance partitioning models (Borcard et al., 1992). Another RDA model was constructed according to the abundance of species $\left[\log _{10}(\mathrm{x}+1)\right.$ transformed data]. In this analysis, only local effects proved to have a significant contribution to variance (conductivity, pan area and Secchi disk transparency), hence no variation partitioning was performed. The significance of the models were tested by $\mathrm{n}=999$ unrestricted Monte-Carlo permutations under the reduced model. All analyses were performed with inter-sample scaling and centring by species using Canoco software for Windows 4.5 (Lepš and Šmilauer, 2003).

In order to fit generalised additive models (GAM) of density data, we first used the variables serving as significant predictors in our RDA models. Among them, compared to the linear model with the Akaike information criterion, the best models were chosen for each species and used for predictions, which meant only the ones with Secchi disk transparency and conductivity (with $\log _{10}$ transformed environmental data). For $B$. orientalis, both variables were chosen as smooth variables, while for $C$. carnuntanus and B. ferox, only Secchi disk transparency was selected. These analyses were carried out in R (R Development Core Team, 2009).

\section{RESULTS}

\section{Distribution and co-occurrence}

Anostracans were found in half of the investigated pans: 47 out of 91 (Fig. 1, Tab. 1). We recorded all the three species that were formerly known to inhabit soda pans. Among them, $B$. orientalis was by far the most frequent. Its collected individuals were six times more numerous in our samples than the specimens of the other two species, and they were present in all the three countries in 29 pans (Tab. 1) as well as in the three major parts of the basin: east of the river Tisza, in the Danube-Tisza interfluve, and in Seewinkel, in Transdanubia.

In Hungary, B. orientalis was found in 9 middle-Hungarian pans in Kiskunság (H12, H13, H14, H18, H23, H41, H42, H44, H46), one pan near the Serbian border (H04) and another one in the northern part of the Great Hungarian Plain (H51). B. orientalis was the most frequent species in both Austria and Serbia. Localities of this species were all across Seewinkel. In Serbia, B. orientalis was present in a small northern pan - Medura (S09) - near the Hungarian border, and in three southern ones near the river Tisza (S02, S03, S05).

C. carnuntanus was found only in 12 pans and its distribution was almost restricted to Hungary. Indeed, it was present only in one Austrian pan [Ochsenbrunnlacke (A09)] and was missing from the 9 Serbian pans. On the other hand, like the most common $B$. orientalis, it was recorded in the same number of Hungarian pans, though its distribution was restricted to Kiskunság in the DanubeTisza interfluve.

$B$. ferox was the rarest species both in relative abundance and distribution (only in 10 pans). However, its distribution included all three countries: it was found mostly in Hungary, in two Austrian pans in Seewinkel [Birnbaumlacke (A02) and Kühbrunnlacke (A05)], and in

Tab. 2. List of the environmental variables used in the statistical analysis.

\begin{tabular}{|c|c|}
\hline Spatial variables & $\begin{array}{l}\text { Nearest pan }(\mathrm{km}) \\
\text { Isolation }(\mathrm{km}) \\
\text { Pan density (no. of pans within an area with a radius of } 20 \mathrm{~km})\end{array}$ \\
\hline Habitat characteristics (local effects) & $\begin{array}{l}\text { Water depth }(\mathrm{cm}) \\
\text { Secchi disk transparency }(\mathrm{cm}) \\
\text { Conductivity }\left(\mathrm{mS} \mathrm{cm}^{-1}\right) \\
\text { TSS }\left(\mathrm{mg} \mathrm{L}^{-1}\right) \\
\text { pH } \\
\text { DO }(\%) \\
\text { DO }\left(\mathrm{mg} \mathrm{L}^{-1}\right) \\
\text { Pan area (ha) } \\
\text { Hydroperiod type } 1 \text { (nominal) } \\
\text { Hydroperiod type } 2 \text { (nominal) } \\
\text { Ratio of open water }(\%)\end{array}$ \\
\hline Land use effects & $\begin{array}{l}\text { Water supply (binomial) } \\
\text { Channelling (binomial) } \\
\text { Disturbancy of structure (binomial) } \\
\text { Ratio of natural habitats in catchment area (\%) } \\
\text { Ratio of agricultural fields in catchment area (\%) } \\
\text { Ratio of human settlements in catchment area (\%) } \\
\text { Grazing pressure (nominal) } \\
\text { Timing of grazing (nominal) }\end{array}$ \\
\hline
\end{tabular}

TSS, total suspendid solids; DO, dissolved oxygen. 
Northern Serbian Bela Bara (S08), near the Hungarian border.

The survey of 8 Hungarian pans resulted in only anostracan nauplii that could not be identified to species level. Ten of the investigated 91 pans proved to be disturbed (H06, H19, H31, H32, H33, H36, A03, A27, S01, S07), e.g. because of illegal fish stocking or probable inflow of pesticides. None of them was inhabited by adult fairy shrimps, and nauplii were found only in one of them (KisPéteri-tó; H36), with a very low abundance $\left(0.15\right.$ ind $\left.\mathrm{L}^{-1}\right)$.

In spring, usually only one species was present in a pan (28 pans, $76 \%$ of all pans with at least one species), but sometimes two were counted ( 7 pans, 19\%), or even all the three species at a time [2 pans, Kelemen-szék (H18) and Zab-szék (H46) in Kiskunság, 5\%]. Apart from the last two cases, B. ferox and B. orientalis co-occurred only in the case of the Austrian Kühbrunnlacke (A05), while the other two pairs occurred in three additional Hungarian pans in Kiskunság: C. carnuntanus was found together with B. ferox in pans H37, H41, H44, and with $B$. orientalis in three separate pools of Böddi-szék.

In summer, only $C$. carnuntanus and B. orientalis were found: the former in one (H44) and the latter in six pans (H04, H18, H41, H44, H45 in the Danube-Tisza interfluve in Hungary along with pans A06 and A22 in Seewinkel).

\section{The role of the environmental factors}

The three species were clearly separated into two groups in both RDA models (Fig. 2). B. orientalis was al- ways positively associated with high conductivity, and the range of conductivity of the three species also showed a similar difference (Tab. 3). Conductivity, together with pan area and Secchi disk transparency, significantly affected density, which local variables together explained $27 \%(\mathrm{~F}=10.73, \mathrm{P}=0.001)$ of variance. In the case of presence-absence data, pure spatial effect (isolation) also explained a significant variation $(2.6 \%, \mathrm{~F}=2.93, \mathrm{P}=0.045)$. Nevertheless, presence was also predominantly determined by the local habitat characteristics (Tab. 4). Land use did not explain significant amount of variation in any of the models.

The GAM models also well illustrated the different strategies among the species (Fig. 3). While B. orientalis was predicted to have high densities only in the case of high conductivity and low Secchi disk transparency, the other two species could also be found lower along the conductivity gradient and even in relatively more transparent waters.

\section{DISCUSSION}

\section{Ecological factors}

Our results show different strategies in the case of the three species, mainly related to the salinity of the pans. Eder (2006) regarded both Branchinecta species as obligatory inhabitants of saline waters in Seewinkel, and considered C. carnuntanus as a facultative element. According to our data, B. orientalis seems to tolerate higher salinities than C. carnuntanus and B. ferox. Fur-
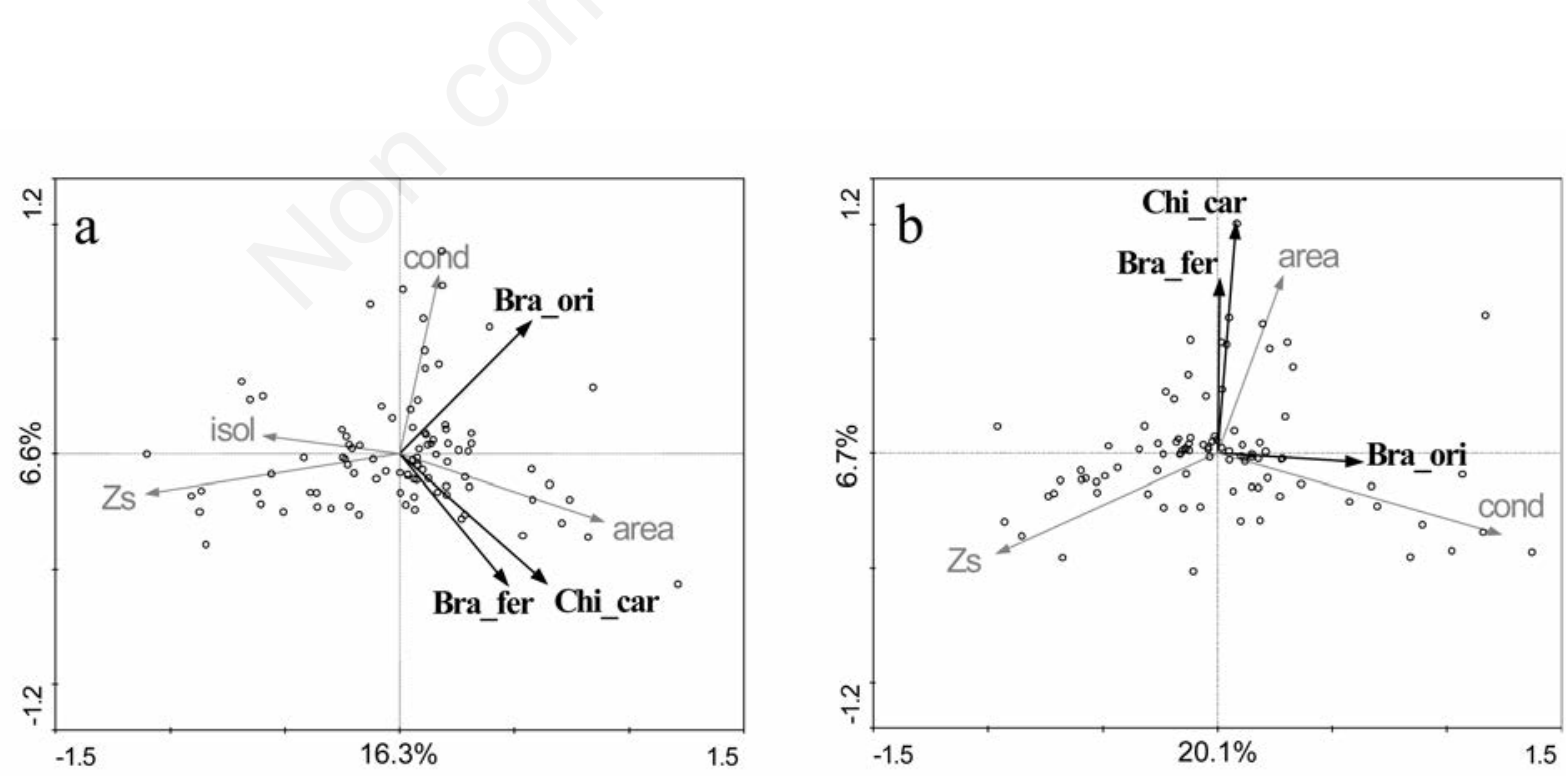

Fig. 2. Redundancy analysis (RDA) models illustrating the relationships between the presence-absence (a) and density (b) data of each species (black arrows) and the significant explanatory variables (grey arrows). Labels used in the figure are: Bra_fer, Branchinecta ferox; Bra_ori, Branchinecta orientalis; Chi_car, Chirocephalus carnuntanus; cond, conductivity; Zs, Secchi disk transparency; area, pan area; isol, isolation. 
thermore, the latter species disappeared in early summer, somewhat earlier than the other two, possibly as a result of the increasing salinity of the pans. In their studies in Spain, Alonso and Comelles (1981) and Alonso (1985) also showed that $B$. ferox preferred cold and not very highly mineralised waters and that the species disappeared as salt concentration increased in the lagoons. Alonso (1985) found the two Branchinecta species to be similar in the persistence of their environment as both occupied mainly temporary waters. Yet, while B. ferox tolerated lower salinity and a turbidity ranging from low to high, $B$. orientalis preferred higher salinity and only low turbidity [the latter species is mentioned in the study as $B$. cervantesi, which is a synonym according to Brtek and Thiéry (1995)]. Conversely, Petkovski (1991) reported that $B$. ferox also preferred rain pools where soil had a high content of mineral salts - especially natron and chlorate -, though exact values of salinity tolerance were not mentioned. Fryer (1983) suggested B. ferox to have a wide eco-physiological tolerance because of the different morphological specialisations of its various life stages.

Alonso $(1985,1990)$ observed that $B$. orientalis at salinity ranges between 0.5 and $4.5 \%$ and that the species did not inhabit freshwater habitats at all, thus he considered it halophilous. Its halophilous characteristic is also confirmed by our results. In soda pans, the total ion concentration $\left(\mathrm{mg} \mathrm{L}^{-1}\right)$ can be calculated by multiplying the conductivity values (expressed in $\mu \mathrm{S} \mathrm{cm}^{-1}$ ) by 0.774 (Boros and Vörös, 2010). According to this, the highest concentration at which $B$. orientalis was found was 7.85 $\mathrm{g} \mathrm{L}^{-1}$ (lowest: 0.62 ), which is a hypo-saline value (Hammer, 1986). Recently, Boronat (2003) found this species in a similar environment in a salt pan in Central Spain, where salinity was $6 \mathrm{~g} \mathrm{~L}^{-1}$. The species is also known from Mongolian salt lakes with salinities ranging from 4.8 to $12.7 \mathrm{~g} \mathrm{~L}^{-1}$ (Alonso, 2010). These waters are also hypo-saline (Hammer, 1986). On the other hand, our results contradict those of Angeler et al. (2008), where $B$. orientalis density correlated negatively with conductivity in some Spanish salt pans.
C. carnuntanus occurred at salinities ranging from 0.54 to $2.48 \mathrm{~g} \mathrm{~L}^{-1}$ and $B$. ferox from 0.46 to $1.94 \mathrm{~g} \mathrm{~L}^{-1}$, in sub-saline pans (Hammer, 1986). In accordance with its former occurrences in temporary freshwater habitats, we can confirm the generalist feature of $C$. carnuntanus suggested by Eder (2006). Boven et al. (2008) also noted that C. carnuntanus could be a habitat generalist, but their results only included five occurrences of the species. $B$. ferox may also be a habitat generalist, but in the Carpathian basin it seems to be highly associated with sodic waters. As the vast majority of Pannonian soda pans belong to the sub-saline lakes and the remaining ones are mainly hypo-saline (Boros, 1999), they represent a suitable habitat for all three anostracans (some pans can even reach the hyper-saline range in summer but these coldwater species disappear by then).

The occurrence of the species was also significantly affected by isolation. Anostracans are passive dispersers, mainly dispersed by wind (Vanschoenwinkel et al., 2008a) and waterbirds (Green et al., 2005). Amphibians (Vanschoenwinkel et al., 2008b) and insects (Beladjal and Mertens, 2009) can also act as vectors, while human-mediated dispersal occurs as well (Waterkeyn et al., 2010). Waterbirds can act as long-distance dispersal vectors (Figuerola and Green, 2002), for instance by linking different pans in the Carpathian basin, especially during migration. On the other hand, our results suggest that the species are less likely present in isolated pans. Moreover, the highest ratios of occupied pans were found in the Seewinkel and Kiskunság areas, having high numbers of pans in restricted areas (although pan density itself was not a significant variable in our models). Similarly, Demeter (2005) found the highest species richness in areas with high number of habitats. This may not be detectable in the case of restricted areas, which can be a reason why Boven et al. (2008) did not find any significant effect of isolation on large branchiopods in Kiskunság. Land use characteristics did not show significant effect in the explanation of variance in the models. This is in line with the results by Angeler et al. (2008), as no effect of regional land use on

Tab. 3. Environmental features of the pans inhabited by the three species in spring.

\begin{tabular}{|c|c|c|c|}
\hline & Branchinecta ferox & Branchinecta orientalis & Chirocephalus carnuntanus \\
\hline Water depth $(\mathrm{cm})$ & $5-60$ & $5-60$ & $9-60$ \\
\hline Secchi disk transparency $(\mathrm{cm})$ & $0.5-5$ & $0.5-27$ & $0.5-12$ \\
\hline Conductivity $\left(\mathrm{mS} \mathrm{cm}^{-1}\right)$ & $0.59-2.1$ & $0.8-10.1$ & $0.7-3.2$ \\
\hline TSS $\left(\mathrm{mg} \mathrm{L}^{-1}\right)$ & $302-13,922$ & $62.5-29,360$ & $498-22,156$ \\
\hline $\mathrm{pH}$ & $8.5-10.2$ & $8.7-10$ & $8.5-10$ \\
\hline DO $(\%)$ & $83.3-115.4$ & 88-139 & $67.8-102$ \\
\hline $\mathrm{DO}\left(\mathrm{mg} \mathrm{L}^{-1}\right)$ & $9.1-12.9$ & $8.3-14.3$ & $8.3-12.9$ \\
\hline Pan area (ha) & $5.8-180$ & $0.5-180$ & $5-180$ \\
\hline Ratio of open water (\%) & $30-90$ & $10-90$ & $5-90$ \\
\hline
\end{tabular}

TSS, total suspendid solids; DO, dissolved oxygen. 
B. orientalis density in Spanish habitats, neither on a small nor on a larger scale, was detected.

Pan area also appeared to have a significant effect on the two least frequent species, B. ferox and C. carnuntanus. This can presumably be a pattern caused by their largescale distribution rather than any real effect of pan area on these species, since they were primarily found in in the Kiskunság area of Central Hungary which has many large pans. In this region, though, they can also be found in very small astatic habitats, e.g. sodic puddles or wheel tracks (Boven et al., 2008; E. Boros personal communication).

\section{Co-occurrences of the species}

Co-occurrence of fairy shrimps in the soda pans (24\%) was relatively low compared to other habitats: Petrov and Cvetković (1997) observed a co-occurrence of $42 \%$ in early spring and Waterkeyn et al. (2009) of $79 \%$. The co-occurrence recorded by Boven et al. (2008), instead, was $31 \%$, thus similar to ours. Still, in the latter two cases, total large branchiopod co-occurrence included Notostraca, Spinicaudata and Laevicaudata species as well.

As the three fairy shrimps are all - at least in the first stages of their life-cycle - filter feeders, they can be competitors when occurring together. Temporal differences in life cycle can play an important role in avoiding interspecies competition in a shared habitat, which is a widely observed phenomenon among anostracans (Petrov and Cvetković, 1997; Abatzopoulos et al., 1999; Moscatello et al., 2002; Thiéry and Puente, 2002; Waterkeyn et al., 2009). According to Thiéry (1991), simultaneous differences in body length can also contribute to resource partitioning as such species presumably feed on particles with different size. Other authors similarly observed that co-occurring fairy shrimp species belonged to different

Tab. 4. Results of the variance partitioning on the presence-absence data.

\begin{tabular}{lccc}
\hline \multicolumn{4}{c}{ Presence-absence } \\
& Explained variance (\%) & F & P \\
\hline$[\mathrm{H}]$ & 20.4 & 7.45 & 0.001 \\
{$[\mathrm{~S}]$} & 3.0 & 7.74 & 0.061 \\
{$[\mathrm{HUS}]$} & 23.1 & 6.44 & 0.001 \\
{$[\mathrm{H} / \mathrm{S}]$} & 20.1 & 7.48 & 0.001 \\
{$[\mathrm{~S} / \mathrm{H}]$} & 2.6 & 2.93 & 0.045 \\
{$[\mathrm{H} \cap \mathrm{S}]$} & 0.4 & & \\
$100-[\mathrm{HUS}]$ & 76.9 & & \\
\hline
\end{tabular}

[H], variation explained by habitat characteristics with no covariables; [S], variation explained by the spatial effect with no covariables; [HUS], variation explained by habitat characteristics and spatial effects; [H/S], pure variation explained by habitat characteristics; $[S / H]$, pure variation explained by spatial variables; [HกS], variation shared by habitat characteristics and spatial variables; 100-[HUS], total unexplained variance.
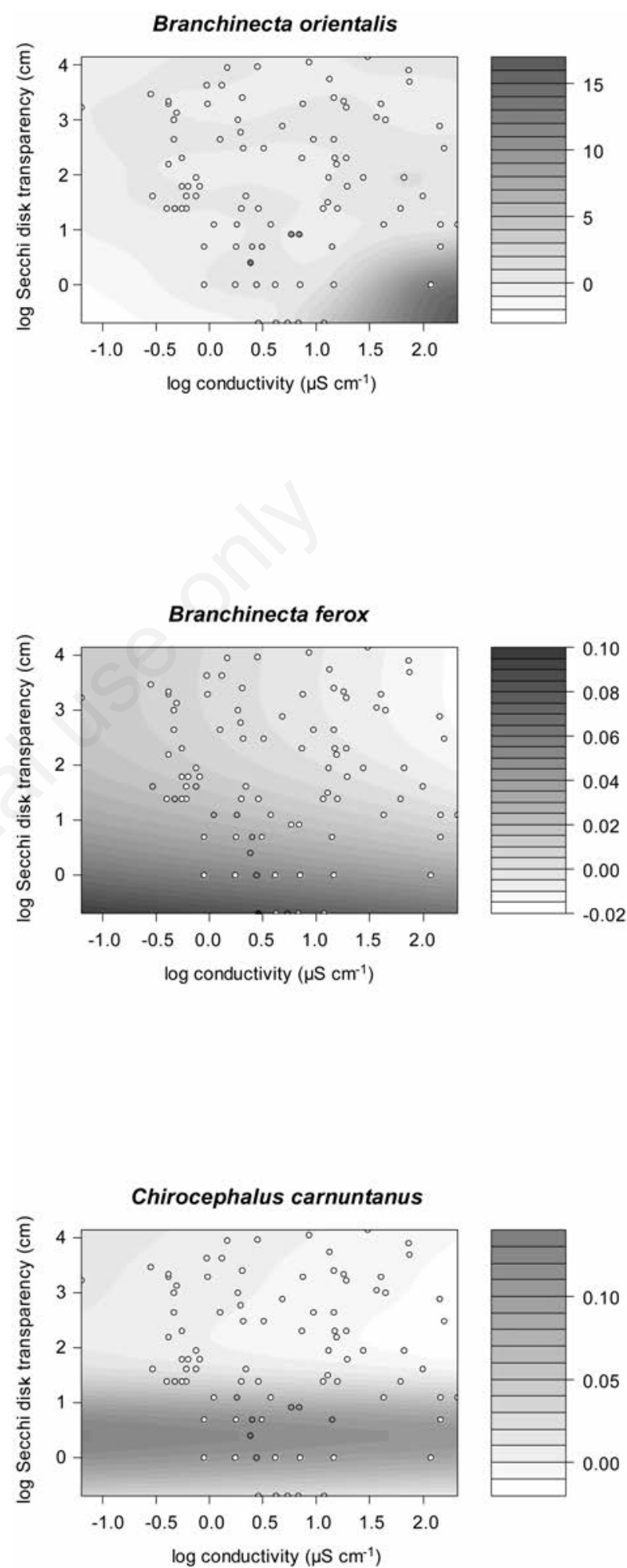

Fig. 3. Generalised additive models (GAM) models for density data (ind $\mathrm{L}^{-1}$ ) of the three species. Points illustrate the original data obtained from the samples, while background shows the predicted values. Colour coding for both variables can be found on the right side of the plots. 
size and/or age classes (Mura, 1991; Hathaway and Simovich, 1996; Thiéry and Puente, 2002; Beladjal et al., 2003), as it is resulted also from this study. The adult sizes of the three species differ: $B$. ferox has a maximal length of $52 \mathrm{~mm}, B$. orientalis $41 \mathrm{~mm}$, while the utmost limit of C. carnuntanus is only $20 \mathrm{~mm}$ (Petkovski, 1993). Additionally, we observed considerable size differences among co-occurring species in the same sample, with a minimum of $1.5 \mathrm{~mm}$ and a maximum of $22.7 \mathrm{~mm}$ (average difference was $8.1 \mathrm{~mm}$ ). This, together with the high amount of available suspended particles, could enable the coexistence of the different species.

\section{Historical and current distribution}

C. carnuntanus was not recorded in Seewinkel between 1968 and 1995 (Eder and Hödl, 2003), and therefore it was considered to be extinct (Löffler, 1993). In 1995, it was rediscovered in Illmitzer Zicksee and Östliche Hutweidenlacke (Eder and Hödl, 1995; Eder and Aescht, 1996; Eder et al., 1996). In 2009-2010, we did not find this species in the former pan (A30), while the latter was part of Lange Lacke in spring 2010 due to the high amount of precipitation. There, instead of C. carnuntanus, B. orientalis was found. However, we registered the species in a new site, i.e., in Ochsenbrunnlacke (A09).

During our study, C. carnuntanus was absent from the Serbian pans, although it had been formerly recorded from temporary waters of the region. Petkovski (1993) described three localities of this species in Vojvodina: two in the vicinity of Melenci (registered in 1965 and 1989) and the pan Okanj (registered in 1971). The former habitats were proved to exist also later on by Petrov and Cvetković (1997). Nonetheless, we found B. orientalis instead of C. carnuntanus in Okanj (S02).

In Hungary, C. carnuntanus was documented in the Danube-Tisza interfluve and the eastern part of the Great Hungarian Plain (Forró, 2000). Yet, these records are mainly from 1890-1959, and the description of the exact locality is usually missing. Recently, the species appeared only in Kiskunság (Forró, 1987; Boven et al., 2008), which highlights the conservational importance of this area. As temporary waters that could also be inhabited by this species are under decline, astatic soda pans are essential habitats for $C$. carnuntanus. Other recent European findings of the species were only in three sites in Romania, by Băile Calacea, Sânnicolau Mare and Timişoara, near the Hungarian and Serbian borders (Demeter and Stoicescu, 2008) and in one site in Western Slovakia in 1996, near Vysoká pri Morave (Lukáš, 2000).

Being the most frequent species in the pans, $B$. orientalis had the widest distribution in the Carpathian basin. Our data included many new localities. In Serbia, it was formerly recorded only in Mala Rusanda (S03) (Petkovski, 1991). We found the species in this pan again in 2010 and documented three new localities: Slano Kopovo (S05), Medura (S09) and Okanj (S02), the latter being the southernmost occurrence of this species in the central European area.

In Seewinkel, B. orientalis has been recorded from several pans, being the most common fairy shrimp of the Austrian pans. We found B. orientalis in 14 Austrian pans, 4 of which (A07, A11, A22, A31) were new records for the species (Eder et al., 1996; Eder and Hödl, 2002). We confirmed 6 formerly known localities (A04, A06, A16, A23, A24, A25; Eder et al., 1996), and discovered this fairy shrimp in Kühbrunnlacke (A05), Sechsmahdlacke (A12), Albersee (A17), and Kirchsee (A20). The latter localities were documented as habitats of Branchinecta spp., but the most recent investigation conducted in 19941995 did not result in any specimens. As former studies in the area often considered $B$. orientalis and B. ferox one species before Petkovski (1991), several previous data are uncertain on the species and therefore indicated here as Branchinecta sp. Among its formerly known Austrian habitats, $B$. orientalis was only missing from Illmitzer Zicksee (A30) in 2009-2010. Löffler (1959) found the species in 15 pans, while Metz and Forró (1991) in 14. According to Eder and Hödl (2003), though, this data should all be treated as Branchinecta spp., due to the uncertainties. On the other hand, considering the taxonomical changes (i.e., some of the above mentioned records may mean B. ferox instead of $B$. orientalis) and the disappearance of some pans like Huldenlacke or Martenthaulacke, which were formerly inhabited by one of the Branchinecta species, we can conclude that $B$. orientalis has a very stable population in Seewinkel.

In Hungary, $B$. orientalis has formerly been recorded from several pans on the southern and north-eastern parts of the Great Hungarian Plain and the Danube-Tisza interfluve (Forró, 2000). Many of them, though, have disappeared by now, mainly due to the significant fall of the groundwater level. Recent occurrences of the species are only known from Central Kiskunság (Forró, 2003; Boros et al., 2006), similarly to C. carnuntanus. Our results include some new data for the current Hungarian distribution of $B$. orientalis, involving the pans $\mathrm{H} 04, \mathrm{H} 23$ and H51, along with some new localities in Central Kiskunság (H12-14, H41, H42, H44). In the other neighbouring countries, $B$. orientalis was only recorded from the eastern part of Romania in 1953, outside the Carpathian basin (Demeter and Stoicescu, 2008).

As the rarest fairy shrimp, $B$. ferox was proved to occur in three Austrian pans in 1994-1995: Birnbaumlacke (A02), Martenhofen-lacken (A07), and Ochsenbrunnlacke (A09) (Eder et al., 1996). We registered the species in two pans: one of them was Birnbaumlacke (A02) while the other, Kühbrunnlacke (A05), was a locality where one of the Branchinecta species had been 
formerly recorded, but it was not confirmed later by the study of Eder et al. (1996). In the light of both our results and those of Eder et al. (1996), we can conclude that a relatively small area (approximately $3 \times 3 \mathrm{~km}$ ) including three of the above mentioned 4 pans (A02, A05, A09) presumably maintains a stable population of $B$. ferox in Seewinkel.

B. ferox was recorded in Serbia only from pools in the vicinity of Melenci in 1965, 1989 and 1991-1995 (Petkovski, 1991, 1993; Petrov and Cvetković, 1997). Therefore, the Northern Bela Bara (S08) is its second registered occurrence in Vojvodina and in Serbia, and the first record for Serbian soda pans.

Hungarian literature on $B$. ferox is mainly from 1858 to 1959 (Forró, 2000). Megyeri (1975) reported new data in the 1970s, but the material he collected was from pans that have dried out and disappeared since then. In the following 40 years, the occurrence of $B$. ferox was registered only in a wheel track (Boven et al., 2008) and in three astatic soda pans [Kelemen-szék (H18), Zab-szék (H46), Böddi-szék (H11-14)] in Kiskunság (Forró, 2003), along with the pan Göbölyös (H49) in the north-eastern part of the Great Hungarian Plain (Forró et al., 1996). Although we did not find B. ferox in Böddi-szék (H11-14) or any fairy shrimp in Göbölyös (H49), we confirmed the presence of B. ferox in Kelemen-szék (H18) and Zab-szék (H46) and additionally registered 5 new localities for the species near the river Tisza (H34, H37), in eastern Hungary (H30) and in the western part of the Danube-Tisza interfluve (H41, H44). Recently, Kerek-szik (H30) is the easternmost occurrence of the species in the region, as its next habitat is in Southern Ukraine by the Black sea, more than $600 \mathrm{~km}$ eastward (Brtek, and Thiéry 1995). In the Carpathian basin, there is no data on B. ferox from Romania (Demeter and Stoicescu, 2008), Slovenia (Brancelj and Gorjanc, 1999), Croatia (Petrov and Marinček, 1991), eastern Czech Republic (Brtek and Thiéry, 1995) or the western part of Ukraine (Brtek and Thiéry, 1995), and, although the species is known from several localities in South-Western Slovakia, its last observation there dates back to 1976 (Brtek, 2005).

\section{CONCLUSIONS}

The two Branchinecta spp. have disjunct distributions in Europe with very similar patterns. Their central European range in the Carpathian basin is the greatest among the patches (Brtek and Thiéry, 1995). This means that our data approximately covers the recent distribution of both species in their central European area, and particularly of $B$. orientalis, as this species has only been documented here in soda pans for a long time. The main and presumably exclusive area of $C$. carnuntanus is also the Carpathian basin and this is the first large-scale study on its actual distribution in the region. Seewinkel and
Kiskunság play an essential role in conserving the three fairy shrimp species. Indeed, they conserved stable populations of all species, presumably because they have been part of the Neusiedler See-Seewinkel and Kiskunság National Parks for a long time. Moreover, they also conserved a high number of pans within relatively small areas. In Hungary, extensive studies on the historical distribution of the species are available. Still, as we could not prove their occurrence in many of their formerly reported habitats - especially in the eastern part of the country - a probable decline in their area of occupancy may have occurred.

Moreover, local land use management seems to have no direct effect on the anostracans, though it can still have a role in changing local conditions, e.g. conductivity, which occurred in the case of the disturbed pans. Our results suggest that habitat management, including grazing and agriculture which are quite regular in the case of most pans (especially in the Hungarian national parks), does not have a side effect on fairy shrimps as long as it does not alter any of the local environmental factors, e.g. salinity or turbidity.

However, the drastic decrease in the number of soda pans threatens the survival of the species in the region, especially that of the halophilous $B$. orientalis. This habitat loss in Kiskunság has been $80 \%$ since the $18^{\text {th }}$ century, and it is mainly due to climatic changes and former human disturbance, primarily drainage, flood control, and irrigation before the establishment of the Kiskunság National Park (Boros and Biró, 1999). In Seewinkel, a similar tendency was observed with the disappearance of approximately $70-85 \%$ of the pans between 1850 and the end of the $20^{\text {th }}$ century (Kohler et al., 1994; Zulka and Milasowszky, 1998).

In Hungary, all soda pans are now protected by law, which provides a good basis for the conservation of the species in the long-term. However, in Serbia, only Slano Kopovo and Okanj are under protection (with plans on the future protection of Rusanda). This calls for conservational measures to save the vulnerable habitats of these fairy shrimps, which are also unique representatives of athalassohaline soda waters in Europe. On the other hand, to conserve them efficiently, it would be highly desirable to nationally protect these anostracans and to include them in the vulnerable category of the IUCN Red List, given their rarity, vulnerability and the decline in their extent of occurrence, especially in the Hungarian part of the Carpathian basin.

\section{ACKNOWLEDGMENTS}

We would like to express our gratitude to the staff of the Hungarian National Park Directorates, the Hortobágy Environmental Association, Zoltán Ecsedi, Attila Pellinger, Balázs Németh and Anna Práger in Hungary; 
Alois Herzig, Richard Haider and Rudolf Schalli in Austria; and László Szőnyi, Ottó Bitó, Attila Ágoston, Ottó Szekeres, Klára Szabados and László Galambos in Serbia for their valuable help in data service or field work. We are also grateful to the LIFE07NAT/H/000324 project for the financial support, to Gergely Horváth and David Kosky for improving the English of the manuscript, and to Robert Ptacnik for his useful suggestions on GAM methodology.

\section{REFERENCES}

Abatzopoulos TJ, Brendonck L, Sorgeloos P, 1999. First record of Branchinella spinosa (Milne-Edwards) (Crustacea: Branchiopoda: Anostraca) from Greece. Int. J. Salt Lake Res. 8:351-360.

Alonso M, 1985. A survey of the Spanish Euphyllopoda. Misc. Zool. 9:179-208.

Alonso M, 1990. Anostraca, Cladocera and Copepoda of Spanish saline lakes. Hydrobiologia 197:221-231.

Alonso M, 2010. Branchiopoda and Copepoda (Crustacea) in Mongolian saline lakes. Mong. J. Biol. Sci. 8:9-16.

Alonso M, Comelles M, 1981. [Criterios básicos para la clasificación limnológica de las masas de agua continentales de pequeño volumen de España], p. 35-42 [in Spanish]. In: Proc. $1^{\text {st }}$ Span. Congr. Limnol., Barcelona, Spain.

Angeler DG, Viedma O, Sánchez-Carrillo S, Alvarez-Cobelas M, 2008. Conservation issues of temporary wetland Branchiopoda (Anostraca, Notostraca: Crustacea) in a semiarid agricultural landscape: what spatial scales are relevant? Biol. Conserv. 141:1224-1234.

Beladjal L, Mertens J, 2009. Diaspore dispersal of Anostraca by flying insects. J. Crustacean Biol. 29:266-268.

Beladjal L, Peiren N, Vandekerckhove TTM, Mertens J, 2003. Different life histories of the co-occurring fairy shrimps Branchipus schaefferi and Streptocephalus torvicornis (Anostraca). J. Crustacean Biol. 23:300-307.

Belk D, 1998. Global status and trends in ephemeral pool invertebrate conservation: implications for Californian fairy shrimp, p. 147-150. In: C.W. Witham, E.T. Bauder, D. Belk, W.R. Ferren Jr. and R. Ornduff (eds.), Ecology, conservation, and management of vernal pool ecosystems. California Native Plant Society ed., Sacramento, CA, USA.

Borcard D, Legendre P, Drapeau P, 1992. Partialling out the spatial component of ecological variation. Ecology 73:10451055.

Boronat MD 2003. [Distribución de los microcrustáceos en lagunas de Castilla-La Mancha. Ciclos estacionales y migración vertical en lagunas cársticas estratificadas]. [in Spanish]. PhD Diss., University of Valencia, Spain.

Boros E, 1999. [A magyarországi szikes tavak és vizek ökológiai értékelése]. [Article in Hungarian]. Acta Biol. Debr. Oecol. Hung. 9:13-80.

Boros E, Bánfi Sz, Forró L, 2006. Anostracans and microcrustaceans as potential food sources of waterbirds on sodic pans of the Hungarian plain. Hydrobiologia 567:341-349.

Boros E, Biró Cs, 1999. [A Duna-Tisza-közi szikes tavak ökológiai állapotváltozásai a XVIII-XX. Századokban]. [Article in Hungarian]. Acta Biol. Debr. Oecol. Hung. 9:81-105.
Boros E, Vörös L, 2010. [A magyarországi szikes tavak sótartalma és ionösszetétele]. [Article in Hungarian]. Acta Biol. Debr. Oecol. Hung. 22:37-51.

Boven L, Vanschoenwinkel B, De Roeck RE, Hulsmans A, Brendonck L, 2008. Diversity and distribution of large branchiopods in Kiskunság (Hungary) in relation to local habitat and spatial factors: implications for their conservation. Mar. Freshwater Res. 59:940-950.

Brancelj A, Gorjanc N, 1999. On the presence of Chirocephalus croaticus (Steuer, 1899) in an intermittent lake in SW Slovenia. Hydrobiologia 412:25-34.

Brendonck L, Rogers DC, Olesen J, Weeks S, Hoeh WR, 2008. Global diversity of large branchiopods (Crustacea: Branchiopoda) in freshwater. Hydrobiologia 595:167-176.

Brtek J, 2005. [Fauna Slovenska: Anostraca - žiabronôžky, Notostraca - štítovky, Spinicaudata - škl'abkovky, Laevicaudata - hrachovky, (Crustacea: Branchiopoda)]. [Book in Slovak]. Slovak Academy of Sciences VEDA Publ., Bratislava: $144 \mathrm{pp}$.

Brtek J, Thiéry A, 1995. The geographic distribution of the European Branchiopods (Anostraca, Notostraca, Spinicaudata, Laevicaudata). Hydrobiologia 298:263-280.

Damgaard J, Olesen J, 1998. Distribution, phenology and status for the larger Branchiopoda (Crustacea: Anostraca, Notostraca, Spinicaudata and Laevicaudata) in Denmark. Hydrobiologia 377:9-13.

Demeter L, 2005. Spatial distribution and conservation status of large branchiopods in the Ciuc basin, Romania. Acta Biol. Debr. Oecol. Hung. 13:73-83.

Demeter L, Stoicescu A, 2008. A review of the distribution of large branchiopods (Branchiopoda: Anostraca, Notostraca, Spinicaudata, Laevicaudata) in Romania. North-West. J. Zool. 4:203-223.

Dimentman C, 1981. The rainpool ecosystems of Israel: geographical distribution of freshwater Anostraca (Crustacea). Israel J. Zool. 30:1-15.

Dvihally ZsT, 1999. [Hazai szikes vizeink kémiai jellege]. [Article in Hungarian]. Acta Biol. Debr. Oecol. Hung. 9:281-292.

Eder E, 2006. [Urzeitkrebse], p. 92-98. [in German]. In: I. Oberleitner, G. Wolfram and A. Achatz-Blab (eds.), Salzlebensräume in Österreich. Umweltbundesamt Publ., Vienna.

Eder E, Aescht E, 1996. [Groß-Branchiopoden in der Sammlung "Evertebrata varia" des OÖ. Landesmuseums (Linz, Österreich)], p. 167-169. [in German]. In: W. Hödl and E. Eder (eds.), Urzeitkrebse Österreichs: Lebende Fossilien in kurzlebigen Gewässern. OÖ Landesmuseums ed., Linz.

Eder E, Hödl W, 1995. Rediscovery of Chirocephalus carnuntanus and Tanymastix stagnalis: new data on large branchiopod occurence in Austria. IUCN Anostracan News 3:2.

Eder E, Hödl W, 1996. [Bestimmungshilfen zur Erkennung heimischer Anostraca, Notostraca und Conchostraca], p. 111136. [in German]. In: W. Hödl and E. Eder (eds.), Urzeitkrebse Österreichs. OÖ Landesmuseums ed., Linz.

Eder E, Hödl W, 2002. Large freshwater branchiopods in Austria: diversity, threats and conservation status, p. 281-289. In: E. Escobar-Briones and F. Alvarez (eds.), Modern approaches to the study of crustacea. Kluwer Academic Publishers, New York.

Eder E, Hödl W, 2003. [Die Groß-Branchiopoden Österreichs. Crustacea: Branchiopoda excl. Cladocera]. [Book in Ger- 
man]. Austrian Academy of Sciences Press, Vienna: 56 pp.

Eder E, Hödl W, Gottwald R, 1997. Distribution and phenology of large branchiopods in Austria. Hydrobiologia 359:13-22.

Eder E, Hödl W, Milasowszky N, 1996. [Die Groß-Branchiopoden des Seewinkels], p. 93-101. [in German]. In: W. Hödl and E. Eder (eds.), Urzeitkrebse Österreichs. OÖ Landesmuseums ed., Linz.

ESRI, 2002. ArcGIS 9.0. Economic and Social Research Institute ed., Redlands.

Figuerola J, Green AJ, 2002. Dispersal of aquatic organisms by waterbirds: a review of past research and priorities for future studies. Freshwater Biol. 47:483-494.

Forró L, 1987. The Branchiopoda fauna of the Kiskunság National Park, p. 67-72. In: S. Mahunka (ed.), The fauna of the Kiskunság National Park. Akadémiai Kiadó ed., Budapest.

Forró L, 1990. Aquatic Crustaceans in the 'Bátorligeti-láp' Nature Reserve in NE Hungary, p. 245-250. In: S. Mahunka (ed.), The Bátorliget Nature Reserves - after forty years. Hungarian Natural History Museum ed., Budapest.

Forró L, 2000. Checklist, distribution maps and bibliography of large branchiopods in Hungary. Miscnea Zool. Hung. 13:4758.

Forró L, 2003. [A Fülöpszállás-Szabadszállás környéki szikes vizek rákfaunája]. [Article in Hungarian]. Természetvédelmi Közlemények 10:241-250.

Forró L, Andrikovics S, Herczeg F, Milinki É, 1996. [A tiszavasvári Göbölyös természeti értékei - érvek a védetté nyilvánítás mellett]. [Article in Hungarian]. Természetvédelmi Közlemények 3:113-121.

Fryer G, 1983. Functional ontogenetic changes in Branchinecta ferox (Milne-Edwards) (Crustacea: Anostraca). Philos. T. R. Soc. Lon. B 303:229-343.

Gottwald R, Eder E, 1999. ["Co-occurrence" - ein Beitrag zur Synökologie der Groß-Branchiopoden]. [Article in German]. Ann. Naturhist. Mus. Wien 101:465-473.

Green AJ, Sánchez MI, Amat F, Figuerola J, Hontoria F, Ruiz O, Hortas F, 2005. Dispersal of invasive and native brine shrimps Artemia (Anostraca) via waterbirds. Limnol. Oceanogr. 50:737-742.

Hammer UT, 1986. Saline lake ecosystems of the world. Dr. W. Junk Publishers, Dordrecht: 616 pp.

Hathaway SA., Simovich MA, 1996. Factors affecting the distribution and co-occurrence of two southern Californian anostracans (Branchiopoda), Branchinecta sandiegonensis and Streptocephalus woottoni. J. Crustacean Biol. 16:669677.

Horváth Zs, Vad CsF, 2010. [A Városligeti-tó rákfaunájának és kisrák együtteseinek (Copepoda, Cladocera) vizsgálata]. [Article in Hungarian]. Hidrológiai Közlöny 90:41-43.

Jungwirth M, 1973. [Populationsdynamik und Populationsrate von Branchinecta orientalis (G. O. Sars) in der Birnbaumlacke (Seewinkel, Burgenland) unter besonderer Berücksichtigung der limnologischen Bedingungen des Gewässers]. [in German]. PhD Diss., University of Vienna, Austria.

Kohler B, Rauer G, Wendelin B, 1994. [Landschaftwandel], p. 21-34. [in German]. In: G. Dick, M. Dvorak, A. Grüll, B. Kohler and G. Rauer (eds.), Vogelparadies mit Zukunft? Ramsar-Gebiet Neusiedler See-Seewinkel. Umweltbundesamt Publ., Vienna.
Lepš J, Šmilauer T, 2003. Multivariate analysis of ecological data using CANOCO. Cambridge University Press, Cambridge: $269 \mathrm{pp}$.

Löffler H, 1959. [Zur Limnologie, Entomostraken. und Rotatorienfauna des Seewinkelgebietes (Burgenland, Österreich)]. [Article in German]. Sitzber. Preuss. Akad. 168:315-362.

Löffler H, 1993. Anostraca, Notostraca, Laevicaudata and Spinicaudata of the Pannonian Region and in its Austrian area. Hydrobiologia 264:169-174.

Lukáš J, 2000. [Výskyt niektorých druhov lupeňonôžok (Crustacea, Branchiopoda) na území Zàpadného Slovenska]. [Article in Slovak]. Folia faunistica Slovaca 5:87-90.

Manca M, Mura G, 1997. On Branchinecta orientalis Sars (Anostraca) in the Himalayas. Hydrobiologia 356:111-116.

Megyeri J, 1975. [A fülöpházi szikes tavak hidrozoológiai vizsgálata]. [Article in Hungarian]. Acta Acad. Ped. Szeged. 2:53-72.

Metz H, Forró L, 1991. The chemistry and crustacean zooplankton of the Seewinkel pans: a review of recent conditions. Hydrobiologia 210:25-38.

Miličić D, Petrov B, 2007. First findings of the clam shrimps Lepthestheria Sars, 1896 and Imnadia Hertzog, 1935 (Crustacea, Conchostraca) in the western foothills of the Stara Planina Mountains, Serbia. Arch. Biol. Sci., Belgrade 59:151-155.

Moscatello S, Belmonte G, Mura G, 2002. The co-occurrence of Artemia parthenogenetica and Branchinella spinosa (Branchiopoda: Anostraca) in a saline pond of south eastern Italy. Hydrobiologia 486:201-206.

Mura G, 1991. Life history and interspecies relationships of Chirocephalus diaphanus Prévost and Tanymastix stagnalis (L.), (Crustacea, Anostraca) inhabiting a group of mountain ponds in Latium, Italy. Hydrobiologia 212:45-59.

Mura G, 2001. Updating Anostraca (Crustacea, Branciopoda) distribution in Italy. J. Limnol. 60:45-49.

Petkovski S, 1991. On the presence of the genus Branchinecta Verrill, 1869 (Crustacea, Anostraca) in Yugoslavia. Hydrobiologia 226:17-27.

Petkovski S, 1993. [Taksonomsko-morfološka i zoogeografskoekološka studija reda Anostraca (Crustacea: Branchiopoda) jugoslovenskih zemalja]. [in Serbian]. PhD Diss., University of Novi Sad, Serbia.

Petrov B, Cvetković DM, 1997. Community structure of branchiopods (Anostraca, Notostraca and Conchostraca) in the Banat province in Yugoslavia. Hydrobiologia 359:23-28.

Petrov B, Marinček M, 1991. On the Anostraca (Crustacea) of Yugoslavia. Hydrobiologia 212:261-212.

Petrov B, Petrov I, 1997. The status of Anostraca, Notostraca and Conchostraca (Crustacea: Brachiopoda) in Yugoslavia. Hydrobiologia 359:29-35.

R Development Core Team, 2009. R: a language and environment for statistical computing. R Foundation for Statistical Computing ed., Vienna. Available from: http://www.r-project.org

Samraoui B, Chakri K, Samraoui F, 2006. Large branchiopods (Branchiopoda: Anostraca, Notostraca and Spinicaudata) from the salt lakes of Algeria. J. Limnol. 65:83-88.

Thiéry A, 1991. Multispecies coexistence of branchiopods (Anostraca, Notostraca \& Spinicaudata) in temporary ponds of Chaouia plain (western Morocco): sympatry or syntopy 
between usually allopatric species. Hydrobiologia 212:117136.

Thiéry A, Puente L, 2002. Crustacean assemblage and environmental characteristics of a man-made solar saltwork in southern France, with emphasis on anostracan (Branchiopoda) population dynamics. Hydrobiologia 486:191200.

V.-Balogh K, Németh B, Vörös L, 2010. [Szervesanyagok magyarországi fehér vizủ szikes tavakban]. [Article in Hungarian]. Acta Biol. Debr. Oecol. Hung. 22:75-86.

Vanschoenwinkel B, Gielen S, Seaman M, Brendonck L, 2008a. Any way the wind blows - frequent wind dispersal drives species sorting in ephemeral aquatic communities. Oikos 117:125-134.

Vanschoenwinkel B, Gielen S, Vandewaerde H, Seaman M, Brendonck L, 2008b. Relative importance of different dis- persal vectors for small aquatic invertebrates in a rock pool metacommunity. Ecography 31:567-577.

Waterkeyn A, Grillas P, De Roeck ERM, Boven L, Brendonck L, 2009. Assemblage structure and dynamics of large branchiopods in Mediterranean temporary wetlands: patterns and processes. Limnol. Oceanogr. 54:1256-1270.

Waterkeyn A, Vanschoenwinkel B, Elsen S, Anton-Pardo M, Grillas P, Brendonck L, 2010. Unintentional dispersal of aquatic invertebrates via footwear and motor vehicles in a Mediterranean wetland area. Aquat. Conserv. 20:580-587.

Zulka KP, Milasowszky N, 1998. Conservation problems in the Neusiedler See-Seewinkel National Park, Austria: an arachnological perspective, p. 331-336. In: P.A. Selden (ed.), Proc. $17^{\text {th }}$ European Colloquium of Arachnology. British Arachnological Society. Burnham Beeches, UK. 